\title{
Reklamın Tüketim Psikolojisi Üzerindeki Etkisinde Nöropazarlamanın Aracılık Rolü
}

\author{
A. Selçuk Köylüoğlu ${ }^{1 *}$ \\ ${ }^{1 *}$ Selçuk Üniversitesi, Kulu Meslek Yüksekokulu, Konya, Türkiye, (ORCID: 0000-0003-0359-1443), selcuk641@gmail.com \\ (International Conference on Design, Research and Development (RDCONF) 2021 - 15-18 December 2021)
}

(DOI: 10.31590 /ejosat.1039362)

ATIF/REFERENCE: Köylüoğlu, A. S. (2021). Reklamın Tüketim Psikolojisi Üzerindeki Etkisinde Nöropazarlamanın Aracılık Rolü. Avrupa Bilim ve Teknoloji Dergisi, (32), 346-352

Öz

Tüketici davranışlarının analizi için pazarlama alanında çok yeni olmasa da nöropazarlama teknikleri kullanılmaya başlanmıştır. Buradan hareketle kurgulanan çalışmanın amacı, reklamın tüketim psikolojisi üzerindeki etkisinde nöropazarlamanın aracılık rolünü ortaya koymaktır. Bu çalışma, nicel verilere dayalı olup, genel ve ilişkisel tarama modelinde gerçekleştirilmiştir. Veriler anket yöntemiyle toplanmıştır. Araştırma evrenini, Konya' nın merkez ilçeleri oluşturmaktadır. Araştırmaya 18 yaş ve üzeri katılımcılar dâhil edilmiştir. Deneklerin seçiminde kolayda örnekleme yöntemi tercih edilmişst ve çalışma 200 gönüllü denekle yürütülmüştür. Veri toplama aracı olarak kullanılan anket formu, tüketim psikolojisi $(n=18)$, reklam $(n=11)$ ve nöropazarlama ( $=5)$ olarak sınıflandırılmıştır. Elde edilen verilerin çözümünde ve yorumlanmasında betimsel istatistikler ile çıkarımsal istatistikler kullanılmıştır. Verilerin kuramsal açıdan uyumunu doğrulamak için Yapısal Eşitlik Modelleri (YEM) çizilmiştir. Bu doğrultuda model, Baron ve Kenny (1986) tarafından geliştirilen üç aşamalı yapısal eşitlik modeli ile test edilmiştir. Sonuç olarak, reklamın tüketim psikolojisi üzerindeki etkisinde nöropazarlamanın aracılık rolünün olduğu tespit edilmiştir.

Anahtar Kelimeler: Nöropazarlama, Reklam, Tüketim Psikolojisi.

\section{The Mediating Role of Neuromarketing in the Effect of Advertising on Consumption Psychology}

\begin{abstract}
Neuromarketing techniques have begun to be used for the analysis of consumer behavior, although they are not very new in the field of marketing. The aim of the study, which is based on this, is to reveal the mediating role of neuromarketing in the effect of advertising on consumer psychology. The research is a general and relational survey model based on quantitative data. Data were collected by questionnaire method. The research population consists of the central districts of Konya. Participants aged 18 and over were included in the study. Convenience sampling method was preferred in the selection of the subjects. And the study was conducted with 200 volunteer subjects. The questionnaire used as a data collection tool was classified as consumer psychology ( $\mathrm{n}=18$ ), advertising $(n=11)$ and neuromarketing $(n=5)$. Descriptive and inferential statistics were used in the analysis and interpretation of the data. Structural Equation Models (SEM) were drawn in order to verify the compatibility of the theoretically established relations with the data in the research. Accordingly, the model was tested with the three-stage structural equation model developed by Baron and Kenny (1986). As a result, it has been determined that neuromarketing has a mediating role in the effect of advertising on consumer psychology.
\end{abstract}

Keywords: Neuromarketing, Advertisement, Consumption Psychology.

* Sorumlu Yazar: selcuk641@gmail.com 


\section{Giriş}

Reklamı basit bir satın aldırma çabası olarak görmek, bugünün pazarlama anlayışıyla asla uyuşmamaktadır. Benzerliği açısından ilişki kurulacak olursa, Lippmann (1922), rızanın üretilmesini, kitlelerin onayını almak için hiçbir şekilde zora ve şiddete başvurmadan iletişim araçları vasıtasıyla tesis edilme süreci şeklinde tanımlamıştır. $\mathrm{Bu}$ yaklaşımın bugünkü reklam anlayışıyla ne kadar benzerlik gösterdiği dikkat çekmektedir. Çünkü reklamlar kitleleri farkında olmadan yani dolaylı olarak manipüle etmektedir. Dolayısıyla, reklam, pek çok alternatif arasında tüketicileri satın almaya teşvik edecek ve bu sayede tüketimi artıracak potansiyele sahip güçlü bir pazarlama iletişimi aracıdır (Herman ve Chomsky, 2012). Sahip olduğu bu potansiyelle ortaya bir tüketim toplumu çıkaran reklam, bireylerde daha çok arzu etme ve daha çok tüketme dürtüleri yaratmaktadır. Burada reklamla yapılmak istenen, şüphesiz, tüketimin sürdürülebilir kılınmasıdır. Bunu sağlamanın en etkili yolu ise, reklamın, tüketicilerin zihinsel süreçleri ile ilgilenen psikoloji bilimiyle sıkı irtibat halinde olmasından geçmektedir (Y1ldırım, 2013).

Reklam ve psikoloji alanının etkileşimi neticesinde, birey dürtüleri harekete geçirilerek satın alma davranışı özendirilmektedir. $\mathrm{Bu}$ iki farklı alanın senkronize uyumu, bireylerin arzularına ancak tüketerek ulaşabilecekleri mesajını vermektedir. James Vicary' nin “Patlamış mısır ye, Coca-Cola iç” deneyi (Karremans vd., 2006) ile Bernays' in "sigara kullanımının kadınları özgür bırakacăğ” anlatısı (Bernays.hr) bu açılamanın en büyük ispatıdır. Aslında reklamlarda kullanılan bu stratejilerle, gerçek olmayan ihtiyaçlar ortaya atılıp, tüketicilerin bu ihtiyaçları gidermelerine yönelik güdülenmeleri sağlanmaktadır. Ve tüketicinin bu davranışını öğrenerek, sonrasında devam ettirmesi beklenmektedir. Psikolojide bu, Skinner' in davranışçılık ekolü ile açıklanmaktadır (Senemoğlu, 2005). Benzer şekilde, reklamla ilişkilendirilebilecek pek çok psikoloji kuramı şu şekilde sıralanabilir:

Tablo 1. Reklamla İlişkilendirilen Psikolojik Kuramlar

\begin{tabular}{|c|c|c|}
\hline Araştırmacı & Kuram & Sonuç \\
\hline $\begin{array}{l}\text { Rosenberg ve } \\
\text { Abelson } \\
\text { Abraham Maslow }\end{array}$ & $\begin{array}{l}\text { Bilişsel } \\
\text { Dengeleme } \\
\text { İhtiyaçlar } \\
\text { Hiyerarşisi }\end{array}$ & $\begin{array}{l}\text { Bireylerin bilişsel ve düşünsel uyumu } \\
\text { sağlama çabalarını ortaya koymuştur. } \\
\text { Temel ihtiyaçlardan başlanarak sırasıyla } \\
\text { diğer ihtiyaçlar giderilmelidir. }\end{array}$ \\
\hline Heider & $\begin{array}{l}\text { Denge } \\
\text { Kuramı }\end{array}$ & $\begin{array}{l}\text { Bireyler tutarsızlıktan kurtulmak için } \\
\text { tutum değişikliğine gidebilmektedir. }\end{array}$ \\
\hline Bluma Zeigarnik & $\begin{array}{l}\text { Zeigarnik } \\
\text { Etkisi }\end{array}$ & $\begin{array}{l}\text { Bölünmüşs şeyler daha kolay } \\
\text { hatırlanmaktadır. }\end{array}$ \\
\hline Tannenbaum & $\begin{array}{l}\text { Tutarlılık } \\
\text { Kuramı }\end{array}$ & $\begin{array}{l}\text { Çelişki içinde olan birey, bu durumun } \\
\text { hafifletilmesi yönünde harekete } \\
\text { geçmektedir. }\end{array}$ \\
\hline $\begin{array}{l}\text { B. Frederick } \\
\text { Skinner }\end{array}$ & $\begin{array}{l}\text { Davranışçılık } \\
\text { Ekolü }\end{array}$ & $\begin{array}{l}\text { Bireylerin davranış tekrarı ile } \\
\text { öğrenmesinin mümkün olduğu } \\
\text { anlaşılmaktadır. }\end{array}$ \\
\hline $\begin{array}{l}\text { Wertheimer, } \\
\text { Köhler\&Koffka } \\
\text { Festinger }\end{array}$ & $\begin{array}{l}\text { Gestalt } \\
\text { Psikolojisi } \\
\text { Bilişsel } \\
\text { Çelişki }\end{array}$ & $\begin{array}{l}\text { Bütün, kendisini oluşturan parçaların } \\
\text { toplamından daha fazladır. } \\
\text { Bireyler tutumlarına ters düşen } \\
\text { davranışlardan kurtulmak için değişik } \\
\text { yollara başvurmaktadır. }\end{array}$ \\
\hline Osgood & $\begin{array}{l}\text { Tutarlılık } \\
\text { Kuramı }\end{array}$ & $\begin{array}{l}\text { Tutarsızlık içindeki birey, durumunun } \\
\text { negatifliğini azaltmak için bilişsel ya da } \\
\text { davranışsal düzeyde eyleme geçmektedir. }\end{array}$ \\
\hline Sigmund Freud & $\begin{array}{l}\text { Psikanaliz } \\
\text { Kuramı }\end{array}$ & $\begin{array}{l}\text { Bireyin zihinsel ya da fiziksel tüm } \\
\text { faaliyetlerini güdülenme ile ger- } \\
\text { çekleştirdiğini öne sürmektedir. }\end{array}$ \\
\hline
\end{tabular}

Tablo 1' e, insan psikolojisi gözetilerek yapılan reklamların dayanağını oluşturması ve reklam-psikoloji ilişkisini ortaya koyması yönüyle yer verilmiştir. Örneğin, Skinner' in çalışmalarından olan, edimsel koşullanma ile ilgili olarak, satın alınan bir ürün çevre tarafından kabul görmüşse ya da çevrenin hoşuna gitmişse, birey o ürünü tekrar satın alır. Ama birey, çevre tarafından eleştiri aldığı bir ürün satın almışsa, bu davranışını tekrar ettirmez (Senemoğlu, 2005). Benzer şekilde, Bluma Zeigarnik tarafindan ortaya atılan Zeigarnik Etkisi' ne göre, yarım kalan şeylerin bireyin tatminini tamamlayamadığı ve reklamların bu sırada devreye girdiği öne sürülmektedir. Reklamların ise tatmini tamamlama vaadi ile tasarlandığ varsayıldığında da netice tüketim olmaktadır (Zeigarnik, 1927). Tutarlılık kuramıyla ilgili olarak da, reklamlar, bireyin reklam perspektifini olumluyarak ve tutum değiştirme stratejilerini kullanarak tüketiciyi ikna etmeye çalışmalıdır. Bunun gibi diğer kuramların da (Heider, 1946; Tannenbaum, 2004; Festinger, 1959; Osgood, 1964; Freud, 1935) reklamla ilişkisi düşünüldüğünde, reklamların tüketim psikolojisi üzerindeki etkisi ile ilgili olarak $\mathrm{H}_{1}$ hipotezi şöyle oluşturulmuştur:

$\mathrm{H}_{1}$. Reklamın tüketim psikolojisi üzerinde pozitif ve anlamlı bir etkisi vardir.

Gelişen teknoloji beraberinde bugünün değişen tüketici profiline yetemez olduğu için, pazarlama ve psikolojiden doğan bu disiplinlerarası yaklaşıma noröbilim de dâhil olarak, geleneksel pazarlamadaki söz konusu boşluk doldurulmaya çalışılmıştır. Çünkü reklam, satın alma davranışında beyindeki karar verme mekanizmalarını, birey-tv yakınlığı gibi etkileme stratejilerini kullanarak başarmaktadır. Burada tüketici nörobiliminin inovatif yaklaşımının rolü büyüktür (Braeutigam vd., 2004; Ambler vd., 2000). Dolayısıyla, tüketici nörobilimiyle elde edilen bulguların yönetimsel olarak uygulanmasını sağlayan, yine tüketici nörobilimi başlığı altında yer alan nöropazarlama, bu yaklaşımın bir çıktısıdır. Literatürde nöropazarlama ile ilgili pek çok tanıma ulaşmak mümkündür (Lee vd., 2007; Murphy vd., 2008; Fisher vd., 2010; Butler, 2008; Senior ve Lee, 2008; Eser vd., 2011). Bu nedenle, yapılan tanımlardan yola çıkılarak, nöropazarlama için şu şekilde genel bir çerçeve çizilebilir: Nöropazarlama, nörobilim tekniklerinin pazarlama uyaranlarına uygulanması olarak geliştirilmiştir (Lee vd., 2007; Weinstein vd., 1984). Burada öne çıkan iki husustan ilki, nöropazarlamanın odak noktasının sadece ticari çıkarlar olmadığını göstermek, ikincisi ise, nöropazarlama araştırmalarının hem kurum içi hem de kurumlararası şeklinde kapsamının genişletilebileceğidir. Kimi araştırmacılar, nöropazarlamanın, reklamlarda kullanılan bilinçaltı mesajlarla tüketicileri satın almaya itmeyi amaçladığını savunmaktadır. Bu kesim araştırmacılara göre, tüketime giden yol beyinden geçmektedir. Ve tüketime yön veren irrasyonel kararlar duyusal uyarıcılarla yönetilebilmektedir. $\mathrm{Bu}$ düşüncenin çıktısı ise, nöropazarlamanın tüketim psikolojisini tetikleyerek alışveriş bozuklukllarına ya da aşırı tüketime neden olacağı yönündedir. Dolayısıyla burada nöropazarlama ve tüketim psikolojisinin birbiri üzerindeki etkisi vurgulanmaktadır (Butler, 2008; Hubert ve Kenning, 2008). Bu duruma, bilinçaltı mesajların kullanılmasının büyük rolünün olduğu varsayılmaktadır (Kelly, 1979). Burada da reklamın nöropazarlama üzerindeki etkisinin altı çizilmektedir. Öyle anlaşılıyor ki, reklamlar, tüketiciyi ikna etme çabasında, tüketim nesnesini olumlama stratejisini baskın olarak kullanmaktadır. $\mathrm{Bu}$ süreçte reklam, nöropazarlama yöntem ve tekniklerinden olabildiğince fazla yararlanmaktadır. 
Diğer bir deyişle, nöropazarlamanın bu süreçteki aracılık rolü barizdir. $\mathrm{Bu}$ açıklamalar doğrultusunda geliştirilen hipotezler şöyle sıralanabilir:

$\mathrm{H}_{2}$. Reklamın nöropazarlama üzerinde pozitif ve anlamlı bir etkisi vardır.

$\mathrm{H}_{3}$. Nöropazarlamanın tüketim psikolojisi üzerinde pozitif ve anlamlı bir etkisi vardır.

$\mathrm{H}_{4}$. Tüketim psikolojisinin nöropazarlama üzerinde pozitif ve anlamlı bir etkisi vardır.

$\mathrm{H}_{5}$. Reklamın tüketim psikolojisi üzerindeki etkisinde nöropazarlamanın aracılık rolü vardır.

$\mathrm{Bu}$ çalışma, reklamın tüketim psikolojisi üzerindeki etkisinde nöropazarlamanın aracılık rolünü araştırmaktadır. Böylece gelişmekte olan nöropazarlama alanına katkı sağlamaktadır. Nöropazarlama araştırmaları genellikle nitel araştırmalardan ibarettir. Nicel araştırmalar noktasında nöropazarlamada bir boşluk olduğu söylenebilir. Dolayısıyla bu çalışma, söz konusu bu boşluğu doldurmaya yönelik katk1 sağlaması bakımından da önem arz etmektedir. Ancak bu konudaki gelecek araştırmalar, nöropazarlamanın nitel ölçüm teknikleriyle de kurgulanabilir.

Çalışma, giriş bölümünün ardından materyal ve metot bölümüyle devam etmektedir. Üçüncü bölüm, araştırma sonucu ve tartışma bölümüdür. Çalışma, dördüncü bölüm olan sonuç bölümüyle tamamlanmıştır.

\section{Materyal ve Metot}

\section{1. Çalışmanın Amacı ve Katkısı}

$\mathrm{Bu}$ çalışma, reklamın tüketim psikolojisi üzerindeki etkisinde nöropazarlamanın aracılık rolünü araştırmaktadır. Böylece gelişmekte olan nöropazarlama alanına katkı sağlamaktadır. Nöropazarlama araştırmaları genellikle nitel araştırmalardan ibarettir. Nicel araştırmalar noktasında nöropazarlamada bir boşluk olduğu söylenebilir. Dolayısıyla bu çalışma, söz konusu bu boşluğu doldurmaya yönelik katk1 sağlaması bakımından da önem arz etmektedir.

\section{2. Çalışmanın Modeli ve Ölçekleri}

Araştırma modeli, literatürde yer alan çalışmalar dikkate alınarak hazırlanmıştır. Aşağıda yer verilen Şekil 1' de; reklamın tüketim psikolojisi üzerindeki doğrudan etkisi $\left(\mathrm{H}_{1}\right)$, reklamın nöropazarlama üzerindeki doğrudan etkisi $\left(\mathrm{H}_{2}\right)$, nöropazarlama ve tüketim psikolojisinin karşılıklı birbiri üzerindeki doğrudan etkileri $\left(\mathrm{H}_{3}-\mathrm{H}_{4}\right)$ ve son olarak, reklamın tüketim psikolojisi üzerindeki etkisinde nöropazarlamanın dolaylı etkisi $\left(\mathrm{H}_{5}\right)$ araştırılmaktadır.

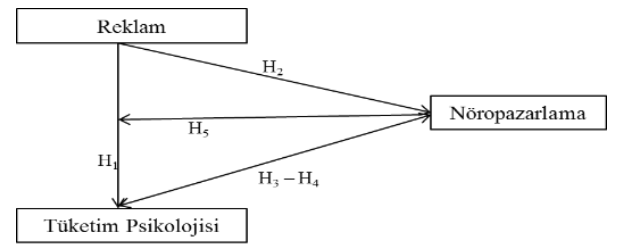

Şekil 1. Araştırma Modeli

Kaynak: Yazar tarafindan geliştirilmiştir.
Bu bağlamda geliştirilen hipotezler şu şekilde sıralanabilir:

$\mathrm{H}_{1}$. Reklamın tüketim psikolojisi üzerinde pozitif ve anlamlı bir etkisi vardır (Zeigarnik, 1927; Tannenbaum, 2004; Osgood, 1964).

$\mathrm{H}_{2}$. Reklamın nöropazarlama üzerinde pozitif ve anlamlı bir etkisi vardır (Kelly, 1979).

$\mathrm{H}_{3}$. Nöropazarlamanın tüketim psikolojisi üzerinde pozitif ve anlamlı bir etkisi vardır (Butler, 2008; Hubert ve Kenning, 2008).

$\mathrm{H}_{4}$. Tüketim psikolojisinin nöropazarlama üzerinde pozitif ve anlamlı bir etkisi vardır (Butler, 2008; Hubert ve Kenning, 2008).

$\mathrm{H}_{5}$. Reklamın tüketim psikolojisi üzerindeki etkisinde nöropazarlamanın aracılık rolü vardır (Braeutigam vd., 2004; Kelly, 1979).

Reklamin tüketim psikolojisi üzerindeki etkisinde nöropazarlamanın aracılık rolünü belirlemeyi test etmek üzere, Baron ve Kenny (1986), tarafindan geliştirilen üç aşamalı model kullanılmıştır. Bu model, doğrudan ve dolaylı etkileri aynı anda analiz edebilme olanağ katılmıyorum' dan 5=Kesinlikle katılıyorum' a doğru 5' li Likert Ölçeği kullanılmıştır.

\section{3. Çalışmanın Ana Kütlesi ve Örneklemi}

Araştırmanın ana kütlesini Konya, örneklemini merkez ilçelerini oluşturan Karatay, Meram ve Selçuklu ilçelerinde ikâmet eden 18 yaş ve üzeri vatandaşlar oluşturmaktadır. Araştırmaya dâhil olan katılımcıların seçiminde, kolayda örnekleme yöntemi tercih edilmiştir (Altunışık vd., 2010). $\mathrm{N}=200$ gönüllü katılımcı ile yürütülen çalışmada, örneklem büyüklüğüne göre, $\% 95$ güvenilirlik sınırları içerisinde ve $\% 5$, lik bir hata payı dikkate alınmıştır.

\section{4. Çalışmanın Veri Toplama ve Analiz Yöntemi}

Çalışmada veri toplama amacıyla kullanılan anket formu üç bölümden oluşmaktadır. Tüketim psikolojisi $(n=18)$, reklam $(n=11)$ ve nöropazarlama $(n=5)$ olarak sınıflandırılmıştır. Veriler, model doğrultusunda elde edilmiştir. Buradan hareketle, her bir değişkenin açıklayıcı faktör analizi SPSS 19 programı yardımıyla yapılmıştır. Sonrasında, AMOS 19 programı ile de, her bir ölçeğin doğrulayıcı faktör analizi gerçekleştirilmiştir. Çalışmanın hipotezleri ve aracılık etkileri ise, yol analizi ile test edilmiştir.

Elde edilen verilerin çözümlenmesi ve yorumlanması için, betimsel ve çıkarımsal istatistikler kullanılmıştır (Özdemir, 2010; Özdamar ve Kuzu, 2015). Verilerin kuramsal ilişkilerinin uyumunu doğrulamak üzere YEM modelleri çizilmiştir. Ölçüm hatalarını bariz bir şekilde ortaya koyması yönüyle bu modeller önemlidir (Meydan ve Şeşen, 2015).

\section{Araştırma Sonuçları ve Tartışma}

Ölçeklerin geçerliliğini test etmek üzere doğrulayıcı faktör analizinden yararlanılmıştır. Tablo 2' de ölçeklerin test edilen yapıları doğrulanmıştır. Bunun için doğrulayıcı faktör analizi ve iç tutarlılık bulguları kullanılmıştır. Ayrıca, Cronbach alfa istatistiği ile her bir ölçeğin güvenilirliliği ölçülmüştür. Son olarak, hipotezleri test etmek üzere yol analizi uygulanmıştır. 


\section{1. Ölçeklerin Doğrulayıcı Faktör Analizi}

Tablo 2. Ölçeklerin Doğrulayıcı Faktör Analizi Sonuçları

\begin{tabular}{|l|l|l|l|l|l|l|l|l|}
\hline Ö.M. & $\boldsymbol{\Delta} \mathbf{X}^{\mathbf{2}}$ & $\mathbf{s d}$ & $\mathbf{p}$ & $\mathbf{\Delta X}^{\mathbf{2}} / \mathbf{s d}$ & GFI & CFI & RMSEA & RMR \\
\hline T.P.Ö.V. & 8.415 & 8 & $.00^{*}$ & 1.05 & .90 & .98 & .02 & .02 \\
\hline R.Ö.V. & 1.721 & 2 & $.00 *$ & .86 & .90 & .95 & .00 & .02 \\
\hline N.Ö.V. & 5.919 & 5 & $.00 *$ & 1.18 & .99 & .96 & .01 & .03 \\
\hline
\end{tabular}

*Ö.M.: Ölçek Modeli, T.P.Ö.V.: Tüketim Psikolojisi Ölçüm Verileri, R.Ö.V.: Reklam Ölçüm Verileri, N.Ö.V.: Nöropazarlama Ölçüm Verileri

(i) $\mathrm{n}=200$, Tüketim Psikolojisi Ölçüm Verileri (T.P.Ö.V.): Cronbach's Alfa=.827, Intraclass Korelasyon $=, 824 \mathrm{~F}=37.124, \mathrm{p}=.000$, Kendall'in W uyumluluk testi $\mathrm{W}=.472, \mathrm{p}=.000$ Chi-Square $=327.423, \mathrm{p}=.000$

(ii) $\mathrm{n}=200$, Reklam Ölçüm Verileri (R.Ö.V.): Cronbach's Alfa $=.850$, Intraclass Korelasyon $=, 843 \mathrm{~F}=15.710, \mathrm{p}=.000$, Kendall'ın $\mathrm{W}$ uyumluluk testi $\mathrm{W}=.364$, $\mathrm{p}=.000$, Chi-Square $=41.563, \mathrm{p}=.000$

(iii) $\mathrm{n}=200$, Nöropazarlama Ölçüm Verileri (N.Ö.V.): Cronbach's Alfa=.823, Intraclass Korelasyon , $820 \mathrm{~F}=9.145, \mathrm{p}=.000$, Kendall'in W uyumluluk testi $\mathrm{W}=$ $.690, \mathrm{p}=.000$ Chi-Square $=123.589, \mathrm{p}=.000$

(iv) $* \mathrm{p}<0,01$ anlamlılık seviyesinde ilişki anlamlı

Tüketim psikolojisi ölçeği uyum iyiliği sonuçlarına bakıldığında; ki-kare 5.415, serbestlik derecesi $8(\mathrm{p}=, 000)$, kikare/serbestlik derecesi $=1.05$, karşılaştırmalı uyum indeksleri NFI .95, TLI .96, IFI .98, yaklaşık hataların ortalama karekökü; RMSEA .02, mutlak uyum indeksleri; GFI .90, AGFI .86, artık temelli uyum indeksi; RMR .02 olarak bulunmuştur. Reklam ölçeği uyum iyiliği sonuçlarına bakıldığında; ki-kare 1.721, serbestlik derecesi 2 ( $\mathrm{p}=, 000)$, ki-kare/serbestlik derecesi $=.86$, karşılaştırmalı uyum indeksleri; NFI .95, TLI .95, IFI .96, yaklaşık hataların ortalama karekökü; RMSEA .00, mutlak uyum indeksleri; GFI .95, AGFI .89, artık temelli uyum indeksi; RMR .02 olarak bulunmuştur. Nöropazarlama ölçeği uyum iyiliği sonuçlarına bakıldığında ise; ki-kare 5.919, serbestlik derecesi 5 $(\mathrm{p}=, 000)$, ki-kare/serbestlik derecesi $=1.18$, karşılaştırmalı uyum indeksleri; NFI .95, TLI .97, IFI .95, yaklaşık hataların ortalama karekökü; RMSEA .01, mutlak uyum indeksleri; GFI .95, AGFI .89 , artık temelli uyum indeksi de; RMR .03 olarak bulunmuştur. Genel olarak sonuçlara bakıldığında; tüketim psikolojisi ölçeği, reklam ölçeği ve nöropazarlama ölçeği uyum indekslerinin oldukça iyi olduğu görülmektedir (Bayram, 2012; Meydan ve Şeşen, 2015; Karagöz, 2016).

\subsection{Korelasyon Sonuçları}

Tablo 3. Betimsel Istatistik ve Basit Korelasyon Analizi Sonuçları

\begin{tabular}{|c|c|c|c|c|c|}
\hline Ölçüm Verileri & $\begin{array}{l}\text { Aritmetik } \\
\text { Ortalama }\end{array}$ & $\begin{array}{l}\text { Standart } \\
\text { Sapma }\end{array}$ & 1 & 2 & 3 \\
\hline $\begin{array}{l}\text { 1.Tüketim } \\
\text { Psikolojisi }\end{array}$ & 2,84 & 1,04 & 1 & & \\
\hline 2. Reklam & 2,90 & 1,46 & ,606** & 1 & \\
\hline 3. Nöropazarlama & 2,52 & 1,17 &, $556^{* *}$ &, $711 * *$ & 1 \\
\hline
\end{tabular}

Tüketim psikolojisi ölçüm verileri, reklam ölçüm verileri ile nöropazarlama ölçüm verileri arasında anlamlı bir ilişkiye ait yapılan basit korelasyon analizi sonuçları tablo 3 , te incelendiğinde; tüketim psikolojisi ile reklam arasında $(\mathrm{r}=+, 606$, $\mathrm{p}<0,01)$ pozitif, orta ve anlamlı bir ilişkinin ve nöropazarlama ile arasında $(\mathrm{r}=+, 556, \mathrm{p}<0,01)$ pozitif, orta ve anlamlı bir ilişkinin olduğu görülmektedir. Öte yandan, reklam ile nöropazarlama arasında $(\mathrm{r}=+, 711, \mathrm{p}<0,01)$ pozitif, yüksek ve anlamlı bir ilişkinin olduğu görülmektedir. Betimsel istatistikler incelendiğinde; tüketim psikolojisi ölçüm verilerinin aritmetik

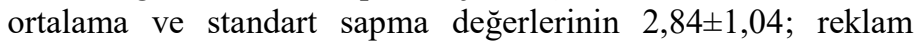

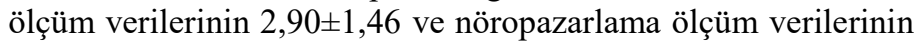
ise, 2,52 $\pm 1,17$ olduğu görülmektedir. Genel bir değerlendirme yapılacak olursa, tüketim psikolojisi, reklam ve nöropazarlama arasında pozitif ve anlamlı, aynı yönlü bir ilişki mevcuttur.
Ancak betimsel istatistiklere bakıldığında, katılımcıların tüketim psikolojisi, reklam ve nöropazarlama algılarının orta ve orta değerin altında bir değere sahip olduğu söylenebilir.

\subsection{Model Testleri}

Reklamın tüketim psikolojisi üzerindeki etkisinde nöropazarlamanın aracılık rolü, Baron ve Kenny (1986) tarafindan geliştirilen yapısal eşitlik modeli ile test edilmiştir. $\mathrm{Bu}$ modelde Baron ve Kenny, üç durumun varlığına dikkat çekmektedir:

(i) Bağımsız değişkenin (reklam) bağımlı değişken (tüketim psikolojisi) üzerinde bir etkisi olmalıdır.

(ii) Bağımsız değişkenin (reklam) aracı değişken (nöropazarlama) üzerinde bir etkisi olmalıdır.

(iii) Aracı değişkenin (nöropazarlama) ikinci adımdaki regresyon analizi dâhil edildiğinde, bağımsız değişkenin (reklam) bağıml değişken (tüketim psikolojisi) üzerindeki etkisi düşerken, aracı değişkenin (nöropazarlama) de bağımlı değişken (tüketim psikolojisi) üzerinde anlamlı bir etkisi olmalıdır.

Belirtilen etkileri araştırmak üzere kurulan iki ayrı model aşağıda yer almaktadır.

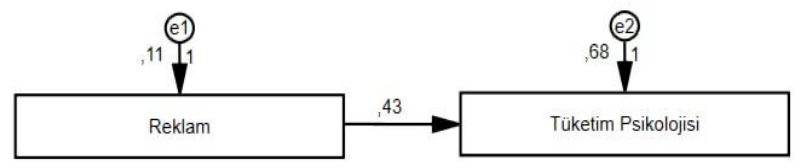

Şekil 2. Model I Test Sonuçlart

Model tasarımından önce, ölçeklerin geçerlilik ve güvenirliği test edilmiştir. Ölçeklerin uyum indeks seviyeleri kabul edilebilir düzeydedir. Cronbach's Alfa iç tutarlılık katsayısı ile Intraclass Korelasyon değerleri de yüksektir (bkz. Tablo 2).

Tablo 4. Model I Yol Katsayıları Analiz Sonuçları

\begin{tabular}{|c|c|c|c|c|}
\hline Yol & $\begin{array}{c}\text { Standardize } \\
\boldsymbol{\beta}\end{array}$ & $\begin{array}{c}\text { Standart } \\
\text { Hata }\end{array}$ & t & p \\
\hline Reklam $\rightarrow$ Tüketim Psikolojisi & +.43 & .040 & 10.712 & $.00^{*}$ \\
\hline \multicolumn{2}{|l}{$(i){ }^{*} \mathrm{p}<0,05$ anlamlılık seviyesinde ilişki anlamlı }
\end{tabular}

Tasarlanan modelle ulaşılan uyum indeksleri, modelin kabul edilebilir düzeyde olduğunu göstermektedir $\left(\Delta X^{2}=10.412 ; \mathrm{df}=9\right.$; mutlak uyum indeksi $(\mathrm{GFI})=.90$; karşılaştırmalı uyum indeksi $(\mathrm{CFI})=.95 ; \quad$ yaklaşık hataların ortalama karekökü $($ RMSEA $)=.00)^{\prime}$ dır. Reklam değişkeninin tüketim psikolojisine giden yoluna ait standardize edilmiş beta, standart hata ve anlamlılık değerleri tablo 4' te gösterilmiştir. Elde edilen bu bulgulara göre, reklamın tüketim psikolojisi üzerinde $\% 43$ oranında anlamlı bir etkiye sahip olduğu görülmektedir. $(\beta=.43$, $\mathrm{p}<.05)$.

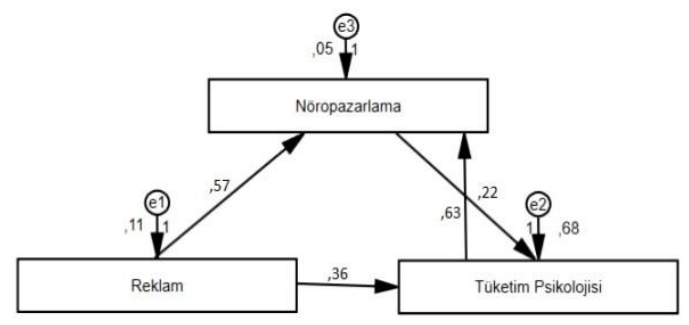

Şekil 3. Model II Test Sonuçları

İkinci modelde tüketim psikolojisi bağımlı, reklam bağımsız ve nöropazarlama ise, aracı değişken olarak ele alınmıştır. 
Böylece, Baron ve Kenny tarafından belirtilen diğer varsayımlar da araştırılmıştır. Modelden elde edilen uyum indeksleri, modelin oldukça iyi olduğunu göstermektedir $\left(\Delta X^{2}=10.178\right.$; $\mathrm{df}=9$; ; mutlak uyum indeksi $(\mathrm{GFI})=.91$; karşılaştırmalı uyum indeksi $(\mathrm{CFI})=.96$; yaklaşık hataların ortalama karekökü $(\mathrm{RMSEA}=.03)^{\prime}$ 'tür. Nöropazarlama ve reklam değişkenlerinden tüketim psikolojisine giden yollara ait standardize edilmiş beta, standart hata ve anlamlılık değerleri tablo 5' te gösterilmiştir. Şekil 3' te gösterilen modelde belirtilen yollara ait standardize edilmiş beta, standart hata ve anlamlılık değerleri tablo 5' te yer almaktadir.

Tablo 5. Model II Yol Katsayıları Analiz Sonuçları

\begin{tabular}{|l|c|c|c|c|}
\hline \multicolumn{1}{|c|}{ Yol } & $\begin{array}{c}\text { Standardize } \\
\boldsymbol{\beta}\end{array}$ & $\begin{array}{c}\text { Standart } \\
\text { Hata }\end{array}$ & $\mathbf{t}$ & $\mathbf{p}$ \\
\hline Reklam $\rightarrow$ Tüketim Psikolojisi & +.36 & .307 & 1.174 & .24 \\
\hline Reklam $\rightarrow$ Nöropazarlama & +.57 & .040 & 14.215 & $.00^{*}$ \\
\hline Nöropazarlama $\rightarrow$ Tüketim Psikolojisi & +.22 & .032 & 7.093 & $.00^{*}$ \\
\hline TüketimPsikolojisi $\rightarrow$ Nöropazarlama & +.63 & .067 & 9.425 & $.00^{*}$ \\
\hline
\end{tabular}

(i) $* \mathrm{p}<0,05$ anlamlılık seviyesinde ilişki anlaml

Elde edilen bulgulara göre, reklam değişkeni, anlamlı olarak nöropazarlama değişkenini etkilemekte $(\beta=.57, \quad \mathrm{p}<0.05)$, nöropazarlama değişkeni, anlamlı olarak tüketim psikolojisini etkilemekte $(\beta=.22, p<0.05)$, tüketim psikolojisi ise anlamlı olarak nöropazarlama değişkenine etki etmektedir $(\beta=.63$, $\mathrm{p}<0.05)$. Genel olarak değerlendirildiğinde, reklamın nöropazarlama üzerinde $\% 57$, nöropazarlamanın tüketim psikolojisi üzerinde $\% 22$, tüketim psikolojisinin nöropazarlama üzerinde ise, \%63 oranında bir etkisi vardır. En yüksek etki, tüketim psikolojisi ile nöropazarlama değişkenleri arasındadır. Tüm bunların yanı sıra, nöropazarlamanın modele dâhil edilmesiyle reklamın $(\beta=.36, \quad \mathrm{p}>0.05)$ tüketim psikolojisi üzerindeki etkisi anlamsızlaşmıştır.

\section{Sonuç}

Disiplinlerarası kavramı süreç odaklı, entegrasyonu vurgulayan ve problem çözen etkili bir yaklaşımdır (Barry vd., 2008; Pohl ve Hirsch, 2007). Nöropazarlama da bu yaklaşımın bir çıktısı olarak görülebilir. Çünkü son zamanlarda, bilinçaltının insanların karar verme sürecini nasıl etkilediğinin anlaşılması yeni yaklaşımların gelişmesini sağlamıştır. Yani bilinçaltı, duygusal zekâ, ikna, irrasyonel kararlar ve daha birçok yeni kavramdan bahsederken tüketicileri sadece rasyonel olarak değerlendirmek doğru değildir (Hazeldine, 2013; Du Plessis, 2011). Bu anlayışta, işin içine nörobilimin dâhil edilmesi gerekmektedir (Mukherji ve Mukherji, 1998). Böylece, nörobilim, psikoloji, antropoloji ve etnografik çalışmalar gibi disiplinler de kendine yer bularak, nöropazarlamanın disiplinlerarası bir formata erişmesine katkı sağlamıştır (Hubert ve Kenning, 2008). O halde, nöropazarlama, nörobilim ile psikoloji ve pazarlama alanlarını bir araya getiren disiplinlerarası bir alan olarak nitelendirilebilir. Ve tüketicilerin bilişsel ve duygusal tepkilerini ölçmeye odaklanır (Karmarkar, 2011).

Yapılan açıklamalar doğrultusunda kurgulanan bu çalışma, reklamin tüketim psikolojisi üzerindeki etkisinde nöropazarlamanın aracılık etkisini test etmeyi amaçlamıştır. Araştırmada örneklem hacmine giren deneklerin reklam, tüketim psikolojisi ve nöropazarlama algıları orta seviyede ve orta seviyenin altında çıkmıştır. Betimsel istatistikler incelendiğinde reklam değişkenine ilişkin standart sapma değeri yüksek çıkmıştır. Bu değer reklam değişkenine ilişkin heterojen bir dağılımın olduğunu yani cevaplarda bir farklılık olduğunu göstermiştir. Reklam, tüketim psikolojisi ve nöropazarlama ölçüm verileri için yapılan doğrulayıcı faktör analizi uyum indeksleri ve iç tutarlılık katsayıları kritik düzeyde yüksektir. Ayrıca ölçüm verileri için intraclass korelasyon katsayıları hesaplanmış olup, ölçüm verileri için de katsayı değerleri yüksek çıkmıştır. Nöropazarlamanın aracı rolü test edilmeden önce reklamın, tüketim psikolojisi üzerinde anlamlı bir etkisinin olduğu gözlemlenmiştir. Bahsi geçen bu etkinin değeri \%43' tür. Nöropazarlama, bu modele aracılık etkisi bakımından müdahil olduğunda ise, reklamın tüketim psikolojisi üzerindeki etkisi anlamsızlaşmış ve etki oranı \%36' ya düşmüştür. $\mathrm{Bu}$ varsayımları ise, yol katsayılarının anlamlılığı için yapılan analizler takip etmiştir. Tüketim psikolojisi nöropazarlama değişkenini anlamlı olarak \%63 oranında etkilemiştir. Etki bakımından, oran olarak modeldeki en yüksek değerdir. Nöropazarlama, tüketim psikolojisi değişkeni üzerinde \%22 oranında anlamlı bir etkiye sahiptir. Bu oran ise, en düşük etki değeridir. Reklam ise, nöropazarlama üzerinde $\% 57$ ' lik anlamlı bir etkiye sahiptir. $\mathrm{Bu}$ bağlamda, araştırmanın temel amacı çerçevesinde öne sürülen Model I ve Model II yol analizleri ile, reklamın tüketim psikolojisi üzerindeki etkisinde nöropazarlamanın aracılık rolünün olduğu sonucuna ulaşılmıştır.

Genel olarak değerlendirildiğinde reklamın nöropazarlama üzerinde $\% 57$, nöropazarlamanın tüketim psikolojisi üzerinde $\% 22$, tüketim psikolojisinin nöropazarlama üzerinde $\% 63$ oranında bir etkisi vardır. En yüksek etki, tüketim psikolojisi ile nöropazarlama değişkenleri arasındadır. Tüm bunların yanı sıra, reklamın $(\beta=.36, p>0.05)$ tüketim psikolojisi üzerindeki etkisi, nöropazarlamanın modele dâhil edilmesiyle anlamsızlaşmıştır. Buna göre reklamın tüketim psikolojisi üzerindeki etkisinde nöropazarlama değişkeni tam aracılık rolüne sahiptir (Braeutigam vd., 2004; Kelly, 1979). Bu sonuca göre, $\mathrm{H}_{2}, \mathrm{H}_{3}, \mathrm{H}_{4}$ ve $\mathrm{H}_{5}$ hipotezleri kabul edilmiştir. Özellikle $\mathrm{H}_{5}$ hipotezinin kabul edilmesi, konu gereği önem arz etmektedir. Ancak $\mathrm{H}_{5}$ hipotezinin kabul edilmesi, yani, nöropazarlamanın aracılık rolünün devreye girmesi, $\mathrm{H}_{1}$ hipotezinde yer alan, reklamın tüketim psikolojisi üzerindeki etkisini anlamsızlaştırmıştır.

Yönetimsel uygulamalar açısından, nöropazarlamanın aracılık rolüne yönelik bu sonuçla ilgili, işletmeler pazarlama iletişimi araçlarını daha dikkatli kullanarak farklı stratejiler geliştirmelidirler. Geleneksel akıldan kurtulup, nöropazarlama gibi post-modernist yaklaşımları ve bunların etkilerini - $b u$ çalışmada olduğu gibi- anbean takip etmelidirler (Mnushko vd., 2016). Ancak bu sayede, işletmeler satış tekniklerini daha etkili bir şekilde kullanmış olurlar ve bu da onların finansal parametrelerinde iyileşme sağlamış olur. Bir diğer belirtilmesi gereken husus, işletmelerin bu süreçte her zaman akademik camia ile dirsek temasında olmalarıdır. Zira nöropazarlama alanındaki ani değişimleri takip etmek ve rekabette önde olmak için bu bilgileri uygulamaya dökmek ancak bu şekilde mümkündür. Dolayısıyla burada üniversite-sanayi işbirliği (Oliveira vd., 2015) öne çıkmaktadır.

Sosyal bilimler alanında yapılan her çalışmada olduğu gibi, bu çalışmanında bazı sınırlılıkları söz konusudur. Çalışma, 200 gönüllü katılımcı ile Konya ilinde gerçekleştirilmiştir. Çalışmanın daha fazla katılımcı ile farklı illerde ya da farklı ülkelerde gerçekleştirilmesi ile daha farklı sonuçlara erişilebilir. Çalışma, önemli bir pazarlama iletişimi aracı olan reklam, nöropazarlama ve pazarlamadan farklı bir alan olan psikoloji üçlü sarmalı üzerine inşa edilmiştir. Benzer şekilde farklı alanlara yer verilmesi ve bu alanların birbiriyle ilişkilendirilmesi daha farklı sonuçlar ortaya koyacaktır. Üzerinde durulması gereken belki de en önemli kısıt, nöropazarlama gibi bir alanda 
nöropazarlama tekniklerinden olan EEG, göz izleme, fMRI vb. nitel ölçüm tekniklerinin kullanılması, daha sağlıklı sonuçların ortaya konulması münasebetiyle elzemdir. Bunun da ötesinde, nöropazarlama etkisi, yapay zekâ, artırılmış gerçeklik, makine öğrenmesi, karar ağaçları, lojistik regresyon gibi çok bağımsız alanlarla ilişkilendirilebilir. Dolayısıyla gelecek araştırmalarda bu hususlara dikkat edilmesi, araştırmalardaki hataların elimine edilerek katma değeri yüksek çalışmaların vücut bulmasını sağlayacaktır.

\section{Teşekkür}

Çalışmanın yayın sürecinde, göstermiş olduğu hassasiyet ve etkili iletişimiyle sağladığı katkılar için Doç.Dr. Zeki ORALHAN' a teşekkür ederim.

\section{Kaynakça}

Abelson, R. P. (1967). Modes of resolution of belief dilemmas. Attitudes versus actions. M. Fishbein (ed.). Readings in attitude theory and research. New York: Wiley.

Altunışık, R., Coşkun, R., Bayraktaroğlu, S., \& Yıldırım, E. (2010). Sosyal Bilimlerde Araştırma Yöntemleri SPSS Uygulamalı (6. Baskı). Sakarya: Sakarya Yayıncılık.

Ambler, T., Ioannides, A. \& Rose, S. (2000). Brands on the brain: Euro-images of advertising. Business Strategy Review, 11, 17-30.

Baron, R. M. \& Kenny, D. A. (1986). The moderator-mediator variable distinction in social psychological research: Conceptual, strategic, and statistical considerations. Journal of Personality and Social Psychology, 51(6), 1173-1182. doi: $10.1037 / / 0022-3514.51 .6 .1173$

Bayram, N. (2012). Veri analizi-Excel ve SPSS uygulamalarıyla birlikte. Ankara: Siyasal Kitabevi.

Bernays, $\underline{\text { https://www.bernays.hr/Home/Page/en-US?name=who- }}$ is-edward-bernaise [09.09.2021]

Braeutigam, S., Rose, S.P.R., Swithenby, S.J. \& Ambler, T. (2004). The distributed neuronal systems supporting choicemaking in real-life situations: Differences between men and women when choosing groceries detected using magneto encephalography. European Journal of Neuroscience, 20, 293-302.

Butler, M. J. (2008). Neuromarketing and the perception of knowledge. Journal of Consumer Behaviour: An International Research Review, 7(4-5), 415-419.

Du Plessis, E. (2011). The branded mind: What neuroscience really tells us about the puzzle of the brain and the brand. Kogan Page.

Eser Z., Isin F. B. \& Tolon M. (2011). Perceptions of marketing academics, neurologists, and marketing professionals about neuromarketing. J. Mark. Manag. 27, 854-868.

Festinger, L. \& Carlsmith, J. M. (1959). Cognitive consequences of forced compliance. Journal of Abnormal and Social Psychology, 58, 203-211.

Fisher, C. E., Chin, L., \& Klitzman, R. (2010). Defining neuromarketing: Practices and professional challenges. Harvard Review of Psychiatry, 18(4), 230-237. http://dx.doi.org/10.3109/10673229.2010.496623

Freud, S. (1935). A general introduction to psychoanalysis. Oxford, England: Liveright.

Hazeldine, S. (2013). Neuro sell. Kogan Page Limited.
Heider, F. (1946). Attitudes and cognitive organization. The Journal of Psychology: Interdis-ciplinary and Applied, 21(1), 107-112.

Herman, E. S. ve Chomsky, N. (2012). Rizanın imalatı: Kitle medyasının ekonomi politiği. (Çev. E. Abadoğlu). 2. Basım. İstanbul: bgst Yayınları.

Hubert, M., \& Kenning, P. (2008). A current overview of consumer neuroscience. Journal of Consumer Behaviour, 7(4-5), 263-271. doi:10.1002/cb.251

Karagöz, Y. (2016). Spss 23 ve Amos 23 uygulamalı istatistiksel analizler. Ankara: Nobel Yayıncilık.

Karmarkar, U. (2011). Note on neuromarketing. Harvard business school marketing unit case, 512-031.

Karremans, J. C., Stroebe, W., \& Claus, J. (2006). Beyond Vicary's fantasies: The 1mpact of subliminal priming and brand choice. Journal of Experimental Social Psychology, 42, 792-798.

Kelly, S. J. (1979). Subliminal embeds in print Advertising: A challenge to Advertising ethics. Journal of Advertising, 8(3), 20-24.

Lee, N., Broderick, A. J., \& Chamberlain, L. (2007). What is 'neuromarketing'? A discussion and agenda for future research. International Journal of Psychophysiology, 63(2), 199-204. http://dx.doi.org/10.1016/j.ijpsycho.2006.03.007

Lippmann, W. (1922). Public opinion. New York: Dower Publication.

Maslow, A. H. (1943). A theory of human motivation. Psychological Review, 50(4), 370-396.

Meydan, C. H. ve Şeşen, H. (2015). Yapısal Eşitlik Modellemesi Amos Uygulamaları. Ankara: Seçkin Yayınevi.

Mnushko, Z.M., Pestun I.V., Timanyuk I.V., Sofronova I.V. \& Aliekperova, N.V. (2016). Management and Marketing in Pharmacy, Dialog Publishing Center, Kharkiv.

Mukherji, A., \& Mukherji, J. (1998). Structuring organizations for the future: Analyzing and Managing change. Management Decision, 36(4), 265-273. doi: $10.1108 / 00251749810211054$

Murphy, E. R., Illes, J., \& Reiner, P. B. (2008). Neuroethics of neuromarketing. Journal of Consumer Behaviour: An International Research Review, 7(4-5), 293-302.

Oliveira, J.H.C., Giraldi, J.d.M.E., Jabbour, C.J.C., Netto, C.F. \& Betti, K.C.M. (2015). Improving business innovation and research through the application of neuromarketing with ethics: A framework', Int. J. Business Innovation and Research, Vol. 9, No.1,52-64.

Osgood, C.E. (1964). Method and theory in experimental psychology, OxfordUniversity Press.

Özdamar, K. N. \& Kuzu, A. (2015). Development and testing of a m-learning system for the professional development of academics through design-based action research. International Review of Research in Open and Distributed Learning, 16(1), 193-220.

Özdemir, M. (2010). Nitel veri analizi: Sosyal bilimlerde yöntembilim sorunsalı üzerine bir çalışma. Eskişehir Osmangazi Üniversitesi Sosyal Bilimler Dergisi, 11(1), 323343.

Pohl, C., \& Hirsch, H. G. (2007). Principles for designing transdisciplinary research: Proposed by the Swiss Academies of Arts and Sciences. oekom Verlag, München.

Senemoğlu, N. (2005). Gelişim öğrenme ve öğretim, kuramdan uygulamaya. Gazi Kitabevi, 12. Bask1, Ankara. 
Senior, C., \& Lee, N. (2008). Editorial: A manifesto for neuromarketing science. Journal of Consumer Behaviour, 7(4-5), 263-271. http://dx.doi.org/10.1002/cb.250

Tannenbaum, D. G. \& Schultz, D. (2004). Inventors of ideas: An introduction to western political philosophy (2nd ed.) by Wadsworth, Thomson Learning, Inc.

Yıldırım, T.E. (2013). Klinik reklamcilık. https://docplayer.biz.tr/15950095-Klinik-reklamcilikreklam-surecinde-psikodinamik-ve-psikolojikrahatsizliklarin-kullanimi.html [09.09.2021]

Zeigarnik, B. (1927). On finished and unfinished tasks- über das behalten von erledigten und unerledigten handlungen, Psychologische Forschung, 9.

Weinstein, S., Drozdenko, R., \& Weinstein, C. (1984). Brain wave analysis in advertising research. Psychology and Marketing, 1, 83-96.

Wertheimer, M. (1912). Experimentelle studien über das sehen von bewegung. Experimental studies on motion vision. Zeitschrift für Psychologie, 61(1), 161-265. 